\title{
Correction to: A New Definition of Voltage Unbalance Using Supply Phase Shift
}

\author{
Aderibigbe Israel Adekitan ${ }^{1}[$
}

Published online: 11 April 2021

(c) The Author(s) 2021

\section{Correction to: Journal of Control, Automation and Electrical Systems (2020) 31:718-725 https://doi.org/10.1007/s40313-020-00579-8}

The article A New Definition of Voltage Unbalance Using Supply Phase Shift, written by Aderibigbe Israel Adekitan, was originally published electronically on the publisher's internet portal on February 14, 2021, without open access. With the author's decision to opt for Open Choice the copyright of the article changed on March 18, 2021, to (T) The Author(s) and the article is forthwith distributed under a Creative Commons Attribution 4.0 International License.

Open Access funding enabled and organized by Projekt DEAL.

The original online version of the article has been updated.

Open Access This article is licensed under a Creative Commons Attribution 4.0 International License, which permits use, sharing, adaptation, distribution and reproduction in any medium or format, as long as you give appropriate credit to the original author(s) and the source, provide a link to the Creative Commons licence, and indicate if changes were made. The images or other third party material in this article are included in the article's Creative Commons licence, unless indicated otherwise in a credit line to the material. If material is not included in the article's Creative Commons licence and your intended use is not permitted by statutory regulation or exceeds the permitted use, you will need to obtain permission directly from the copyright holder. To view a copy of this licence, visit http://creativecommons. org/licenses/by/4.0/.

Open Access This article is licensed under a Creative Commons Attribution 4.0 International License, which permits use, sharing, adaptation, distribution and reproduction in any medium or format, as long as you give appropriate credit to the original author(s) and the source, provide a link to the Creative Commons licence, and indicate if changes were made. The images or other third party material in this article are included in the article's Creative Commons licence, unless indicated otherwise in a credit line to the material. If material is not included in the article's Creative Commons licence and your intended use is not permitted by statutory regulation or exceeds the permitted use, you will need to obtain permission directly from the copyright holder. To view a copy of this licence, visit http://creativecommons.org/licenses/by/4.0/.

Publisher's Note Springer Nature remains neutral with regard to jurisdictional claims in published maps and institutional affiliations.

The original article can be found online at https://doi.org/10.1007/ s40313-020-00579-8.

Aderibigbe Israel Adekitan

aderibigbe-israel.adekitan@tu-ilmenau.de

1 Department of Electrical Engineering and Information Technology, Technische Universität Ilmenau, Ilmenau, Germany 